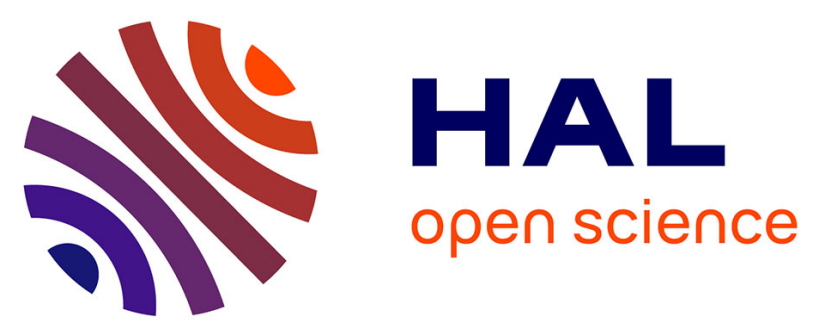

\title{
Reply to Zhongzhong Chen, Hua Xie, and Fang Chen's Letter to the Editor re: Vuthy Ea, Anne Bergougnoux, Pascal Philibert, et al. How Far Should We Explore Hypospadias? Next-generation Sequencing Applied to a Large Cohort of Hypospadiac Patients. Eur Urol 2021;79:507-15
}

Anne Bergougnoux, Vuthy Ea, Françoise Paris, Nicolas Kalfa

\section{- To cite this version:}

Anne Bergougnoux, Vuthy Ea, Françoise Paris, Nicolas Kalfa. Reply to Zhongzhong Chen, Hua Xie, and Fang Chen's Letter to the Editor re: Vuthy Ea, Anne Bergougnoux, Pascal Philibert, et al. How Far Should We Explore Hypospadias? Next-generation Sequencing Applied to a Large Cohort of Hypospadiac Patients. Eur Urol 2021;79:507-15. European Urology, In press, 10.1016/j.eururo.2021.03.033 . hal-03198202

\author{
HAL Id: hal-03198202 \\ https://hal.science/hal-03198202
}

Submitted on 19 Apr 2021

HAL is a multi-disciplinary open access archive for the deposit and dissemination of scientific research documents, whether they are published or not. The documents may come from teaching and research institutions in France or abroad, or from public or private research centers.
L'archive ouverte pluridisciplinaire HAL, est destinée au dépôt et à la diffusion de documents scientifiques de niveau recherche, publiés ou non, émanant des établissements d'enseignement et de recherche français ou étrangers, des laboratoires publics ou privés. 


\section{Reply to Zhongzhong Chen, Hua Xie, and Fang Chen's Letter to the Editor re: Vuthy Ea, Anne Bergougnoux, Pascal Philibert, et al. How Far Should We Explore Hypospadias? Next-generation Sequencing Applied to a Large Cohort of Hypospadiac Patients. Eur Urol 2021;79:507-15}

Exploring the genetic etiology of human defects has advanced over the past decade as a result of technical progress. The gene-by-gene approach has given way to genome-wide association studies and large panel analyses to determine the etiology of hypospadias. We thank the Shanghai team for their interest in our study [1] and for raising exciting points regarding alternative approaches to identifying the pathophysiology of urethral plate defects.

Selecting the genes for study is complicated. Using the Human Protein Atlas for testis gene expression studies is a valuable option. It nevertheless has limitations: (1) it does not focus on developmental genes or provide a dynamic view of fetal gene expression and tissue development, and data on the testis expression profile during fetal lifeespecially during the masculinization window-are not currently documented in this database; (2) numerous genes, although expressed in testis, are ubiquitous; and (3) genes of interest may be expressed in the testis, genital tubercle, and urethral plate. We thus preferred a rational approach based on genes reported to be associated with hypospadias or relative conditions, expressed in developing genital tubercle and gonads, or identified in animal knockout models. This method considered cost, capacity to interpret data, and the likelihood of data being integrated into a coherent clinical approach. A larger process to discover new genes is also a valuable option. However, in this case whole-exome or whole-genome sequencing would be the preferred choice.
As our colleagues rightly note, a genetic burden analysis to identify an excess of rare sequencing variants (RSVs) from exome or genome sequencing must show significant differences between cases and controls. Our philosophy is different: we focused, as in clinics, on identifying potentially causative RSVs in genes suspected to be implicated in hypospadias. Rather than statistical analysis, the point here is the manual curation of each RSV, patient by patient, to select only those with high potential for impact using stringent and validated criteria [2,3]. Our approach and that of the Shanghai group are not in fact mutually exclusive, and new candidate genes identified by large statistical analysis could be implemented in the selected panel analysis.

Finally, our study did include loss of function (LOF) variants and some, although rare, were described. Interpreting LOF variants is quite easy and their impact on phenotypes is quite straightforward, but interpreting missense variants is more delicate, requiring manual processing. Variants have various effects that depend on their location (eg, functional domain) or the gene function. Several syndromes that include hypospadias are caused by gain-of-function variants (eg, Noonan syndrome). More importantly, partial LOF due to hypomorphic variants (eg, mild androgen insensitivity syndrome) is consistent with minor phenotypes such as hypospadias.

This last point agrees with the idea that the frequency of variants in the general population does not systematically call into question their pathogenicity. The relatively high frequency in the general population of some retained variants in our series is comparable to the allelic frequency of well-known pathogenic variants associated with other mild disorders (eg, R117H;T7 variant in the CFTR gene, associated with congenital and bilateral absence of the vas deferens but with very low cystic fibrosis penetrance [4]).

The immense technical progress in sequencing now brings us back to another sizeable challenge: our ability to 
interpret variants while processing an ever-increasing volume of data.

Conflicts of interest: The authors have nothing to disclose.

Acknowledgments: This work was supported by a public grant from Programme Hospitalier de Recherche Clinique (PHRC UF8270) and by public funding from the National Reference Network for Rare Disease, Genital Development (CRMR CRMR DevGen). The sponsors did not play any direct role in the study.

\section{References}

[1] Ea V, Bergougnoux A, Philibert P, et al. How far should we explore hypospadias? Next-generation sequencing applied to a large cohort of hypospadiac patients. Eur Urol 2021;79:507-15. http://dx.doi. org/10.1016/j.eururo.2020.12.036.

[2] Ioannidis NM, Rothstein JH, Pejaver V, et al. REVEL: an ensemble method for predicting the pathogenicity of rare missense variants. Am J Hum Genet 2016;99:877-85. http://dx.doi.org/10.1016/j.ajhg. 2016.08.016.

[3] Richards S, Aziz N, Bale S, et al. Standards and guidelines for the interpretation of sequence variants: a joint consensus recommendation of the American College of Medical Genetics and Genomics and the Association for Molecular Pathology. Genet Med 2015;17:405-24. http://dx.doi.org/10.1038/gim.2015.30.

[4] Thauvin-Robinet C, Munck A, Huet F, et al. The very low penetrance of cystic fibrosis for the R117H mutation: a reappraisal for genetic counselling and newborn screening. J Med Genet 2009;46:752-8. http://dx.doi.org/10.1136/jmg.2009.067215.
Anne Bergougnoux ${ }^{\mathrm{a}, \mathrm{b}, \mathrm{c}}$

Vuthy Ea ${ }^{a, b}$

Françoise Paris ${ }^{\mathrm{a}, \mathrm{b}, \mathrm{d}, \mathrm{e}}$

Nicolas Kalfa ${ }^{\text {a.f.g.* }}$

${ }^{a}$ Centre de Référence Maladies Rares DEVGEN Constitutif Sud, CHU de Montpellier, Montpellier, France

'baboratoire de Génétique Moléculaire, IURC, CHU de Montpellier,

Montpellier, France

'PhyMedExp, CNRS, INSERM, Université de Montpellier, Montpellier, France ${ }^{\mathrm{d}}$ Unité d'Endocrinologie Pédiatrique, Service de Pédiatrie, Hôpital Arnaud de Villeneuve, CHU de Montpellier, Montpellier, France 'Développement Embryonnaire Précoce, Fertilité et Environnement, INSERM, Université de Montpellier, Montpellier, France ${ }^{\mathrm{f}}$ Chirurgie et Urologie Pédiatrique, Hôpital Lapeyronie, $\mathrm{CHU}$ de Montpellier, Université de Montpellier, Montpellier, France

${ }^{\mathrm{g}}$ Institut Desbrest d'Epidémiologie et de Santé PubliqueUMR INSERM Université de Montpellier, France

*Corresponding author. CHU de Montpellier, 371 Avenue du Doyen Gaston Giraud, 34295 Montpellier, Cedex 5, France. Tel. + 33467338 784;

Fax: +33467339512.

E-mail address: n-kalfa@chu-montpellier.fr (N. Kalfa). 